\title{
1.3.1. Postawy wobec edukacji włączającej - jakie skutki?
}

DOI: $10.47050 / 65591838.44-53$

Iwona Chrzanowska

Analizy wyników badań naukowych nie pozostawiają wątpliwości, że powodzenie działań włączających zależy od akceptacji tej idei przez nauczycieli (Avramidis, Kalyva 2007; Jordan, Schwartz, McGhie-Richmond 2009; Rakap, Kaczmarek 2010). Wsparcie z ich strony jest wręcz niezbędne (Ross-Hill 2009).

Dokonując przeglądu literatury naukowej, głównie wyników badań nad zagadnieniem postaw nauczycieli wobec edukacji włączającej, ważne jest, by uświadomić sobie, że model ten ewoluował i nadal ewoluuje. Zmieniać się zatem może nastawienie nauczycieli, gdyż związane jest ono bardziej z chwilowym (krótszym bądź dłuższym) doświadczeniem albo uzyskaną informacją (nabytą wiedzą dotyczącą chociażby istotnych zmian oświatowych pod wpływem idei) czy wreszcie emocji z tym związanych. Postawy jednak mają bardziej trwały charakter (Murray, Morgan 1945 [za: Mika 1987]).

Początkowo w większości krajów proces włączania edukacyjnego utożsamiano z obecnością w klasie zwykłej szkoły ogólnodostępnej ucznia z zaburzeniami, z zakłóceniami w rozwoju. Ma to znaczenie dla rozpoznawania uwarunkowań kształtowania się postaw nauczycieli, zrozumienia ich nastawienia do idei włączania, a także określenia perspektywy ich zmiany $w$ tym zakresie.

Skoncentrowanie się na uczniu ze specjalnymi potrzebami edukacyjnymi, w tym z niepełnosprawnością, skutkowała myśleniem o edukacji włączającej z punktu widzenia problemów, trudności związanych z nietypowymi trajektoriami rozwoju dziecka, obawami nauczycieli związanymi z możliwością sprostania potrzebom, ale także wymaganiom ucznia. W tym okresie okazało się, że największym wyzwaniem, 
jakie edukacja włączająca stawiała przed nauczycielem, było spojrzenie na ucznia z punktu widzenia nie tyle jego zaburzeń i trudności, ile możliwości oraz szans rozwojowych. Dość szybko również pojawiła się refleksja, że idea włączania powinna rekomendować odejście od wszelkiej kategoryzacji uczniów z uwagi na ich charakterystyki rozwojowe (Nukkarinen 2010). Obecnie coraz częściej myśląc o szkole włączającej, wskazuje się na potrzeby nie tyle konkretnej grupy, ile wszystkich uczniów. Ma być ona placówką, w której wsparcie jest naturalnym procesem uruchamianym w momencie, gdy okaże się ono niezbędne, i trwającym tak długo, jak będzie to konieczne. Różnice indywidualne łatwiej jest wówczas traktować jako zasób niż przeszkodę czy utrudnienie na drodze do osiągnięcia sukcesu w działaniach edukacyjnych (Chrzanowska 2018, s. 24).

Współczesne analizy zagadnienia pozwalają wnioskować o nastawieniach nauczycieli względem edukacji włączającej. Część z nich wskazuje na akceptację idei (Black-Hawkins, Florian, Rouse 2010; Szumski 2010, s. 159). Pojawiają się jednak i głosy przeciwne, wyrażające niepokój wobec perspektywy kształcenia wszystkich uczniów w ramach edukacji ogólnodostępnej (Forlin 2001) czy wręcz sprzeciw wobec wspólnej nauki np. z uczniami z niepełnosprawnością intelektualną (Gajdzica 2011, s. 60,77-78). Widoczne jest również swoiste warunkowanie postaw akceptujących. Nauczyciele wskazują, jakie warunki powinny, a nawet muszą być spełnione, by można było myśleć o powodzeniu działań włączających.

Wśród obserwowanych postaw, zwłaszcza tych mniej przychylnych wobec edukacji włączającej, w wynikach badań międzynarodowych powtarzają się kwestie dotyczące:

$\rightarrow$ Realnych możliwości włączenia w ramach edukacji ogólnodostępnej uczniów z niepełnosprawnością o większym stopniu lub z niektórymi rodzajami niepełnosprawności (np. intelektualnej). Wizja tzw. bezwarunkowej inkluzji w tych sytuacjach skutkuje mniej pozytywnymi postawami nauczycieli (Avramidis, Norwich 2002). Z badań Zenona Gajdzicy wynika, że 85\% z nich uważa, że szkoła ogólnodostępna nie jest dobrym miejscem kształcenia dla uczniów z niepełnosprawnością intelektualną w stopniu lekkim (Gajdzica 2011, s. 60, 77-78).

$\rightarrow$ Uznawania przez nauczycieli, że praca z uczniem ujawniającym zaburzenia emocjonalne i zaburzenia zachowania jest trudniejsza, stanowi większe wyzwanie i nie umożliwia płynnego włącze- 
nia go w proces edukacji w szkole ogólnodostępnej (Avramidis, Bayliss, Burden 2000; Forlin 2001; Kniventon 2004).

$\rightarrow$ Konieczności większego zaangażowania czasowego ze strony nauczyciela w pracę z uczniem ze specjalnymi potrzebami edukacyjnymi (Paliokosta, Brandford 2010; Smith, Smith 2000; Valeo 2008) - zarówno na lekcji, jak i podczas przygotowywania się do zajęć poza godzinami dydaktycznymi. Nauczyciele postrzegają to jako dodatkowe obciążenie zawodowe.

$\rightarrow$ Konieczności korzystania z odpowiednich środków dydaktycznych (których niejednokrotnie brakuje), dostosowanych do potrzeb uczniów ze specjalnymi potrzebami (Scruggas, Mastropieri 1996).

$\rightarrow$ Zbyt dużej liczebności klas (Smith, Smith 2000), co, zdaniem nauczycieli, może uniemożliwiać efektywną indywidualizację zajęć (Scruggas, Mastropieri 1996).

$\rightarrow$ Braku wiedzy i kompetencji nauczycieli w zakresie pracy z dzieckiem ze specjalnymi potrzebami po wielu latach od wprowadzania edukacji włączającej (Westwood 2013; Gajdzica 2011; Al.-Khamisy 2004; Błeszyńska 1992; Garlej-Drzewiecka 2004; Łaś 2001; Oleńska-Pawlak 1992; Wachowiak 1992). Z tym problemem wiąże się także zagadnienie braku specjalistycznej kadry wspomagającej (Oleńska-Pawlak 1992), ponadto braku satysfakcjonujących możliwości dokształcania. Pojawiają się również obawy o zwiększenie obowiązków, którym nauczyciele będą musieli podołać w związku z pojawieniem się większej grupy uczniów ze specjalnymi potrzebami (Koutrouba, Vamvakari, Steliou 2006).

$\rightarrow$ Braku treści dotyczących włączania w programach kształcenia nauczycieli na poziomie wyższym i braku nastawienia na kształtowanie podczas studiów kompetencji do pracy w warunkach włączania (Mitchell, Hedge 2007; Bartnikowska, Wójcik 2004; Gajdzica 2001).

$\rightarrow$ Niedostosowania budynków i otoczenia do potrzeb uczniów z niepełnosprawnością (Chrzanowska 2010).

Jedną z barier edukacji włączającej, wymienionych zarówno w badaniach polskich, jak i międzynarodowych, są kompetencje nauczycieli, a właściwie przeświadczenie pedagogów, że ich nie posiadają lub uzyskali je w stopniu niewystarczającym do osiągnięcia sukcesu w pracy z uczniem ze specjalnymi potrzebami. 
Powodzenia działań związanych z edukacją włączającą nie należy jednak uzależniać - z kilku przynajmniej powodów - od kompetencji nauczycieli. Nieodparcie nasuwa się refleksja, że istotną przyczyną poczucia nieprzygotowania do pracy $z$ "innym" uczniem jest głoszona przez lata idea o koniecznej indywidualizacji kształcenia podopiecznych z tej grupy. Badacze, zarówno teoretycy, jak i praktycy związani z pedagogiką specjalną, postulowali konieczność indywidualizacji sposobu pracy z osobami z zaburzeniem (zakłóceniem) rozwoju, czyniąc z tego zasadę nadrzędną. Dosłowne traktowanie tego postulatu skutkuje naturalnym lękiem przed uczniem, którego "inność" uniemożliwia wykorzystanie w pracy jakiejkolwiek ze znanych nauczycielowi strategii postępowania. Jeśli jednak za Krzysztofem Konarzewskim (2011, s. 14) zadamy sobie pytania: „Kto jest inny?", „Od kogo?”, „Pod jakim względem?”, dochodzimy do konkluzji, że wszyscy ludzie i wszyscy uczniowie różnią się od siebie. Biorąc to pod uwagę, trzeba stwierdzić, że nauczyciele na jakimś etapie swojej pracy musieli się z "innym" uczniem zetknąć i w tej sytuacji dali sobie lepiej lub gorzej radę.

Wydaje się ponadto, że argument braku kompetencji (lub ich niskiego poziomu) bywa wykorzystywany instrumentalnie jako najprostsze, a zarazem skuteczne uzasadnienie sprzeciwu wobec edukacji włączającej. Trudno zaprzeczyć, że kompetencje są podstawą skutecznej pracy w każdym zawodzie. Nikt również nie zbagatelizuje zgłaszanego problemu i nie weźmie odpowiedzialności za możliwe negatywne skutki działań niekompetentnych nauczycieli, którzy dodatkowo otwarcie o swoich brakach mówią.

Trzeba jednak pamiętać, że kompetencje zawsze można podnieść. Zawód nauczyciela, podobnie jak większość współczesnych profesji, wymaga ciągłego doskonalenia się. Idea uczenia się przez całe życie przestała być odczytywana jako przywilej bardziej świadomej części społeczeństwa, a stała się koniecznością, a wręcz obowiązkiem każdego pracownika. Wynika on z nieustannych i coraz szybszych zmian zachodzących w każdej ze sfer życia. W związku z tym wyjściowy brak kompetencji coraz rzadziej staje się istotną przeszkodą w projektowaniu i realizowaniu zmian, $w$ tym także w edukacji. Nie uda się powstrzymać przeobrażeń szkolnictwa, wykorzystując ten argument.

Poczucie posiadania lub braku kompetencji u nauczycieli można porównać z subiektywną oceną własnego stanu zdrowia u każdego człowieka. Dwie osoby z identyczną diagnozą medyczną mogą swoją 
sytuację odczuwać zgoła odmiennie. Jedna z nich będzie twierdziła, że jest zdrowa, druga, że choruje i cierpi. Każda z nich prawdopodobnie nie mija się z prawdą, gdyż poczucie bycia zdrowym lub chorym (a także kompetentnym albo niekompetentnym) jest uwarunkowane wieloma zmiennymi.

Problematyce kompetencji i doskonalenia zawodowego nauczycieli oraz ich uwarunkowań poświęcono wiele badań. Niektóre z nich, np. TALIS (Teaching and Learning International Survey) z 2013 r., pozwalają porównać wyniki z różnych krajów. Na ich podstawie można stwierdzić m.in., że polscy nauczyciele częściej niż ich koledzy z 32 państw uczestniczą w różnych formach doskonalnia zawodowego.

Tabela 1. Uczestnictwo nauczycieli w różnych formach doskonalenia zawodowego

\begin{tabular}{l|c|c}
\multicolumn{1}{c|}{ FORMA DOSKONALENIA ZAWODOWEGO } & POLSCY NAUCZYCIELE & ŚREDNIA DLA TALIS \\
\hline kursy doskonalące & $81 \%$ & $71 \%$ \\
\hline konferencje/seminaria & $52 \%$ & $44 \%$ \\
\hline sieci współpracy & $41 \%$ & $38 \%$ \\
\hline mentoring, hospitacje, coaching & $45 \%$ & $30 \%$ \\
\hline indywidualne/wspólne badania & $38 \%$ & $31 \%$ \\
\hline szkolenia poświęcone problematyce SPE & $54 \%$ & $28 \%$ \\
\hline szkolenia poświęcone indywidualizacji pracy z uczniem z SPE & $49 \%$ & $36 \%$
\end{tabular}

Źródło: Hernik (red.) 2014, s. 23-24.

Mniej optymistyczne dla polskich nauczycieli są jednak dane dotyczące ich poczucia wsparcia w rozwoju zawodowym. Okazuje się, że ok. $40 \%$ z nich częściowo i ok. $30 \%$ w całości pokrywa koszty związane z doskonaleniem zawodowym (średnia dla badania TALIS wynosi odpowiednio: $11 \%$ i $12 \%$ oraz $5 \%$ i $9 \%$ ). Polscy nauczyciele mają również mniejszy wybór w zakresie "refundacji" ich zaangażowania w doskonalenie. $Z$ danych wynika, że mniej popularne niż średnio w badaniu TALIS jest stosowanie dodatku motywacyjnego do pensji z tytułu doskonalenia zawodowego. Zaledwie nieco ponad $5 \%$ polskich nauczycieli otrzymało taki dodatek (średnia dla TALIS - 8\%). Rzadziej również stosowane są w Polsce niefinansowe formy wsparcia, np. dni wolne, urlopy szkoleniowe 
- ok. $10 \%$ pedagogów deklaruje, że uzyskało takie wsparcie, przy średniej TALIS wynoszącej 14\% (Hernik [red.] 2014, s. 28).

Jeśli przyjrzeć się zjawisku doskonalenia zawodowego w odniesieniu do idei edukacji włączającej, to najbardziej interesujące są wskaźniki dotyczące nauczycieli ze szkół i z przedszkoli ogólnodostępnych. W założeniu to właśnie tego rodzaju placówki mają brać udział w edukacji włączającej, sieć tych instytucji jest bowiem najbardziej rozbudowana.

$Z$ badań realizowanych w Polsce wynika, że nauczyciele z placówek ogólnodostępnych mają mniej dodatkowych kwalifikacji (uzyskanych poza kierunkowym wykształceniem) niż nauczyciele szkół integracyjnych oraz specjalnych. W tej pierwszej grupie posiadanie takich kwalifikacji deklaruje $35,8 \%$ badanych, w drugiej-ok. $58 \%$, w trzeciej-niemal $80 \%$. Porównywalne grupy nauczycieli z każdego rodzaju szkół planują natomiast podjęcie działań w tym zakresie ( $61 \%$ z ogólnodostępnych i specjalnych, $66 \%$ z integracyjnych). Dane wskazują na zróżnicowanie zasobów w postaci posiadanych dodatkowych kwalifikacji w zależności od etapu edukacyjnego, na którym pracują nauczyciele. W szkołach ogólnodostępnych najczęściej dysponują nimi nauczyciele z klas IV-VI szkół podstawowych (ok. 44\%), najrzadziej z klas VI-VIII i szkół ponadpodstawowych (28\%). Podobną tendencję możemy obserwować w planowaniu działań w tym zakresie. Inaczej sprawa wygląda wśród nauczycieli z placówek specjalnych. W tej grupie im wyższy etap kształcenia, tym większy odsetek posiada dodatkowe kwalifikacje wspierające ich kompetencje edukacyjne. W przypadku planów doskonalenia tendencja jest tu analogiczna jak w placówkach ogólnodostępnych - im wyższy etap kształcenia, tym mniejsza liczba nauczycieli zamierza podnosić swoje kwalifikacje (Chrzanowska 2019, s. 230).

Z punktu widzenia edukacji włączającej ciekawe są powody planowania doskonalenia zawodowego przez nauczycieli. Najczęściej wskazywali oni: chęć poprawienia swojej pozycji zawodowej, finansowej oraz zabezpieczenie się przed możliwością utraty pracy. Tylko w przypadku nauczycieli z placówek ogólnodostępnych wśród trzech

Badania zrealizowano w 2016 r. na grupie ok. 2 tys. nauczycieli z placówek ogólnodostępnych, integracyjnych i specjalnych z całej Polski (edukacja przedszkolna, wczesnoszkolna, klasy IV-VI oraz gimnazjum). Przeprowadzono je tuż przed wejściem w życie reformy systemu oświaty z $2017 \mathrm{r}$., Ustawa z dnia 14 grudnia 2016 r. - Prawo oświatowe (Dz.U. z 2017 r. poz. 60 ze zm.). Pełne wyniki dostępne są w publikacji I. Chrzanowskiej Nauczyciele o szansach i barierach edukacji włączającej. 
najistotniejszych przyczyn znalazła się kwestia braku umiejętności lub wiedzy (zastąpiła ona "zabezpieczenie się przed utratą pracy"). Niezależnie jednak od etapu edukacyjnego, na którym pracują nauczyciele, jest to powód wymieniany na trzecim miejscu, dodatkowo im wyższy etap kształcenia, tym mniejsza liczba nauczycieli wskazuje go jako jeden z najistotniejszych (wczesna edukacja - 33,3\%, klasy IV-VI szkoły podstawowej-20,9\% i szkoła ponadpodstawowa - 19,3\%) (Chrzanowska 2019, s. 232). Wyniki badań potwierdzają istnienie niebezpiecznej tendencji związanej z poczuciem braku stabilizacji zawodowej wśród nauczycieli. Sporo wskazuje na to, że każda z wymienionych grup traktuje doskonalenie zawodowe jako zabezpieczenie przed utratą pracy lub argument $w$ walce o wyższą pensję.

Innym zagadnieniem wartym przeanalizowania w związku z postawami wobec edukacji włączającej jest poziom satysfakcji zawodowej, zadowolenia z pracy lub - z drugiej strony - poczucia obciążenia zawodowego. Satysfakcja z wykonywanej profesji oznacza możliwość zaspokajania przez jednostkę własnych potrzeb, osiągania celów, pielęgnowania wartości i przekonań, a to jest z kolei podstawą kształtowania się postaw wobec zadań zawodowych (Bartkowiak 2009, s 119). Z badań wynika, że zadowolenie z wykonywanych obowiązków wpływa korzystnie zarówno na efekty pracy, jak i na samopoczucie pracownika (Bańka 2000; Zalewska 2009). Brak satysfakcji obniża skuteczność działania i przyczynia się do szybkiego wypalenia zawodowego (Poraj 2009, s. 274). Poczucie zadowolenia (bądź niezadowolenia) wynika z różnych czynników występujących w środowisku zawodowym. Pozytywne nazywane są motywatorami i są wśród nich: dokonania, uznanie, treść pracy, odpowiedzialność, awans, możliwości rozwoju. Do braku satysfakcji przyczyniają się tzw. czynniki higieny, do których zalicza się: relacje interpersonalne, warunki pracy, organizację, kierownictwo i wynagrodzenie (Sowińska 2014).

Jednym z istotnych źródeł satysfakcji zawodowej nauczycieli jest prestiż zawodu - im niższy, tym zadowolenie z wykonywanego zawodu się zmniejsza (Federowicz, Haman, Herczyński 2013, s. 38). Badania zrealizowane w 2016 r. ${ }^{2}$ w grupie ok. 2 tysięcy nauczycieli pracujących w placówkach ogólnodostępnych, integracyjnych i specjalnych wska- 
zują, że poczucie wysokiego prestiżu zawodu towarzyszy nielicznym osobom. Uzyskane rezultaty są bardzo niepokojące - niewielu ankietowanych z placówek ogólnodostępnych zgadza się ze stwierdzeniem "praca nauczyciela ma wysoki prestiż". Dodatkowo, na podstawie tendencji rozkładu wyników można przyjąć, że im wyższy etap edukacyjny, tym mniejsza liczba nauczycieli podpisuje się pod tym stwierdzeniem.

Tabela 2. Prestiż zawodu nauczyciela w opiniach nauczycieli z placówek ogólnodostępnych

\begin{tabular}{l|c|c}
\multirow{2}{*}{ ETAP EDUKACYJNY (PLACÓWKA OGÓLNODOSTĘPNA) } & \multicolumn{2}{|c}{ PRACA NAUCZYCIELA MA WYSOKI PRESTIŻ } \\
\cline { 2 - 3 } & TAK & RACZEJ TAK \\
\hline przedszkole & $3,4 \%$ & $20,2 \%$ \\
\hline klasy I-III szkoły podstawowej & $1,85 \%$ & $9,25 \%$ \\
\hline klasy IV-VI szkoły podstawowej & $0,97 \%$ & $4,33 \%$ \\
\hline gimnazjum & $0 \%$ & $9,2 \%$
\end{tabular}

Źródło: I. Chrzanowska, badania własne.

Tabela 3. Prestiż zawodu nauczyciela w opiniach nauczycieli z placówek integracyjnych

\begin{tabular}{l|c|c}
\multirow{2}{*}{ ETAP EDUKACYJNY (PLACóWKA INTEGRACYJNA) } & \multicolumn{2}{|c}{ PRACA NAUCZYCIELA MA WYSOKI PRESTIŻ } \\
\cline { 2 - 3 } & TAK & RACZEJ TAK \\
\hline przedszkole & $4,1 \%$ & $15,2 \%$ \\
\hline klasy I-III szkoły podstawowej & $2,96 \%$ & $2,44 \%$ \\
\hline klasy IV-VI szkoły podstawowej & $0 \%$ & $6,8 \%$ \\
\hline gimnazjum & $0 \%$ & $5,4 \%$
\end{tabular}

Źródło: I. Chrzanowska, badania własne.

Tabela 4. Prestiż zawodu nauczyciela w opiniach nauczycieli z placówek specjalnych

\begin{tabular}{l|c|c}
\multirow{2}{*}{\multicolumn{2}{c}{ ETAP EDUKACYJNY (PLACÓWKA SPECJALNA) }} & \multicolumn{2}{|c}{ PRACA NAUCZYCIELA MA WYSOKI PRESTIŻ } \\
\cline { 2 - 3 } & TAK & RACZEJ TAK \\
\hline przedszkole & $0 \%$ & $6,5 \%$ \\
\hline klasy I-III szkoły podstawowej & $5,8 \%$ & $7,3 \%$ \\
\hline klasy IV-VI szkoły podstawowej & $4,4 \%$ & $4,4 \%$ \\
\hline gimnazjum & $2,96 \%$ & $1,94 \%$
\end{tabular}

Źródło: I. Chrzanowska, badania własne. 
Wyniki badań Iwony Chrzanowskiej wskazują, że jedynie 1,56\% nauczycieli z placówek ogólnodostępnych, 1,68\% z integracyjnych i 3,7\% ze specjalnych ma poczucie wysokiego prestiżu swojego zawodu. Jeśli się uwzględni dwie pozytywne kategorie: „tak" i „raczej tak", to odsetek ten wzrasta do odpowiednio: 12,2\%,10,3\% i 8,6\%. Są to wskaźniki znacznie gorsze niż w innych krajach. Średnia dla 32 państw biorących udział w badaniu TALIS wynosi 31\% (wskaźnik poniżej 5\% uzyskano w Szwecji, we Francji i w Słowacji, najwyższy - 84\% - w Malezji). Odsetek nauczycieli twierdzących, że ich zawód jest doceniany przez społeczeństwo, wyniósł w tym badaniu 18\% (Piwowarski i in. 2015, s. 38).

Polscy nauczyciele czują ciężar społecznej oceny swojej profesji, zdając sobie jednocześnie sprawę z wiążących się z nią wysokich wymagań i dużej odpowiedzialności. To właśnie te czynniki okazują się najsilniejszymi obciążeniami zawodowymi, wyprzedzając inne, np. pracę w grupie zróżnicowanej czy trudności wychowawcze. Blisko połowa $(49,97 \%)$ badanych nauczycieli z placówek ogólnodostępnych wskazuje je jako czynniki silnie ich obciążające, niewiele jednak niższe są wskaźniki dotyczące trudności wychowawczych $(48,6 \%)$ i pracy w grupie zróżnicowanej $(47,2 \%)$. Warto w tym miejscu odnieść się również do wyników badań nauczycieli z placówek integracyjnych. Dla nich większym obciążeniem w pracy zawodowej są trudności wychowawcze (zgadza się z tym stwierdzeniem ok. 52\% pytanych), następnie praca w grupie zróżnicowanej $(47,4 \%)$ i społeczna ocena zawodu - 44,2\% (Chrzanowska 2019, s. 256).

Inni badacze w grupie czynników obciążających wymieniają również: przeciążenie pracą (Pyżalski 2010c, s. 31; Piwowarski i in. 2015, s. 38), brak pewności zatrudnienia (Piwowarski i in. 2015, s. 38), niskie zarobki (Fedorowicz i in. 2013, s. 39; Pyżalski 2010b, s. 53-54; Piwowarski i in. 2015, s. 38), a także: przeładowane programy i plany nauczania, współpraca z rodzicami uczniów (Pyżalski 2010b, s. 53, 69) oraz z innymi nauczycielami (Pyżalski 2010a, s. 109).

Z analiz wynika także, że wielu nauczycieli w Polsce żałuje wyboru zawodu - ok. 20\% „raczej" lub „zdecydowanie" twierdzi, że nie wybrałoby ponownie tej profesji, 10\% żałuje, że zostało nauczycielem, a ok. 30\% kadry gimnazjum zastanawia się, czy korzystniejsza nie byłaby inna droga zawodowa (Hernik 2014, s. 39). Badania zrealizowane przez Iwonę Chrzanowską wskazują nieco niższe wartości - 7,2\% nauczycieli z placówek ogólnodostępnych, 8,1\% z integracyjnych i 17,4\% ze specjalnych nie wybrałoby tego zawodu, gdyby ponownie miało taką możliwość. 
W dużym stopniu prawdziwe będzie stwierdzenie, że obecnie polscy nauczyciele są sfrustrowani, czują się silnie obciążeni obowiązkami, które na nich spoczywają, i zaniepokojeni zmianami - zarówno znanymi, jak i oczekiwanymi. Nie jest tajemnicą, że edukacja włączająca również oznacza zmiany, jednak, jak stwierdzono wcześniej, większość nauczycieli popiera tę ideę. Ponadto, jak wynika z badań, na pytanie: „Czy edukacja włączająca jest dobrym rozwiązaniem dla uczniów ze specjalnymi potrzebami edukacyjnymi (w tym uczniów z niepełnosprawnością)?" odpowiedzi „tak" udzieliło 75\% nauczycieli z placówek ogólnodostępnych, ok. $80 \%$ z integracyjnych i 58\% ze specjalnych. $\mathrm{Na}$ to pytanie, ale dotyczące uczniów sprawnych, odpowiedzi twierdzącej udzieliło: 73\% nauczycieli z placówek ogólnodostępnych, 71,6\% z integracyjnych i 73,4\% ze specjalnych (Chrzanowska 2019, s. 119). Wydaje się, że obok akceptacji dla edukacji włączającej pojawia się wśród nauczycieli także obawa, jak będzie ona realizowana. Niepokoją się o to, że pozostaną sami z problemami, których być może jeszcze sobie nie uświadamiają, że zapanuje chaos, oddziałujący przede wszystkim na uczniów, ale pośrednio dotykający również nauczycieli. Krzysztof Konarzewski (2004) przewrotnie opisał stawiane im wymagania: „Nauczyciel ma skutecznie nauczać, ale nie stresować, wymagać, ale nie narzucać, utrzymywać dyscyplinę, ale wyrzec się przymusu, być sprawiedliwy, ale w każdym znaleźć coś dobrego, pomagać słabszym i nie zaniedbywać zdolnych. I nade wszystko ma z poświęceniem pracować - dokształcać się i doskonalić zawodowo, troszczyć się o szkolne i pozaszkolne losy każdego ucznia, działać na rzecz lokalnego środowiska, utrzymywać kontakt z nowatorską pedagogiką. Wszystko to ma robić, nie patrząc na zegarek, nie licząc pieniędzy, nie żądając lepszych warunków pracy".

Pytanie postawione w tytule niniejszego podrozdziału - „Postawy nauczycieli wobec edukacji włączającej - jakie skutki?" - było w zamierzeniu przewrotne. Większa część nauczycieli deklaruje bowiem (i nie jest to żadnym zaskoczeniem) akceptację idei edukacji włączającej. Na wysnucie tego wniosku pozwalają analizy badań, zarówno międzynarodowych, jak i polskich. Jednocześnie jednak kadra pedagogiczna coraz odważniej, a raczej - z większą determinacją - wypowiada się na temat tego, co im utrudnia realizację zadań zawodowych. Od wsłuchania się w te potrzeby, a tak naprawdę od reakcji na nie, będzie zależało powodzenie działań włączających, a także przyszłość tego zawodu. 